\title{
The Third Relation of Comparative Literature and East Asian literature
}

\author{
ZHANG Zhejun*
}

\section{The Concept of the Third Relation of Comparative Literature}

In over one century since the inception of Comparative Literature, there have been only two models in the study of literary relationships in the academic communities at home and abroad, that is, influence study and parallel study, with the former studying the communications among different literatures, and the latter studying literary phenomena without communications, comparing the differences and similarities of literary phenomena and pointing to general literature. Various theories of Comparative Literature are sometimes applied in the study of literary relations but this does not change literary relations. Sometimes, influence study and parallel study are combined in research, with parallel study conducted on the basis of influence study, but such study still does not change the nature of the two kinds of relations. The biggest problem with the study of literary relations is that the two models of research cannot cover all literary relations, as there are in fact other literary relations, which will inevitably lead to various problems: with the present models of literary relation study we cannot study so many literary relations, even though we obviously feel the existence of communications and some similar factors between literatures of different countries, and the feasibility of conducting literary relation study. But influence study cannot be conducted, as no evidences verifying literary relations can be found, and similar factors cannot be attributed to the influence relation of specific texts. Once such similar factors are declared to be resulting from the influence relation of texts, a predicament of insufficient and unreliable evidences may ensue, and even a wrong conclusion may be drawn. If such similar factors are deemed as parallel relations, they do not look like parallel relations, because there are richer similar factors than parallel relations, and it would deviate from facts

* ZHANG Zhejun 張哲俊 is professor in school of Chinese Language and Literature of Beijing Normal University. 
with a parallel study. The study of literary relations cannot break through its predicaments because all literary relations are supposed to be either influence or parallel relations. As parallel relations are in fact no relations, literary relations are virtually reduced to one influence relation. Such a research model is not consistent with the facts of literary relations, which are not so simple. As many literary relations do not belong to influence or parallel relations, the imposition of these two modes to all relations can only produce numerous errors or lead to the sense of powerlessness on the part of researchers. The academic communities, however, still put up with these two models for study, as they have no other choice because only influence relations and parallel relations have been found at home and abroad over 100-plus years, and no other literary relation has been discovered.

As a matter of fact, besides relations of influence and parallel relations, there is a third kind of relation in Comparative Literature, that is, the third relation, a literary relation completely different from influence relation or parallel relation. The third relation refers to a literary relation which has no communicative relation at the literary level but has a communicative relation arising from the living world, therefore completely different from the influence relation by nature. The nature of the influence relation is the existence of a communicative relation at the literary level, with the task of influence study being to restore such a communicative relation. The third relation has no communicative relation at the literary level, as poets have no direct contact or the experience of reading the other's texts. Poets of different countries may have the third relation even if they do not know the existence of the other party. The third relation differs from the parallel relation by nature, as the parallel relation means the existence of similar factors despite the existence of any communicative relation either at the literary level or in the living world, but the similar factors are derived from symbiosis. The world of human existence always has some similar factors, while similar natural conditions, social environment and social development stage may give rise to similar phenomena. However, such similar factors are not formed through communication, and the relation among them can only be termed the parallel relation. The difference between the third relation and the parallel relation is that the similar factors in the third relation are not derived from symbiosis, but from the communicative relation in the living world. This communicative relation is not literary communication but communication in the living world. As the living world in different states and nations is formed through communication, there are always some similarities, and even a living world community may be developed. Poets, who live in a living world formed through communication, describe their living world, and similar factors of the living world formed through communication, thereby naturally having an indirect relation 
with the literatures of other states and nations. This indirect relation is the third relation, established with the living world as an inter-medium, and is therefore concealed, which accounts for its not being discovered until now.

The focus of research on the third relation is the communicative relation in the living world, which must be premised on the restoration of the living world. If the living world is not restored, it would not be possible to study the communicative relation in the living world, or understand whether the living world is developed through communication. This means that the study of the third relation must be literary archaeology, which means the restoration of the living world in the age when a poet lives through poem clusters. The living world to a poet means all the environment and events in which he lives, which are history for later generations. Therefore, the communication of the living world is in fact the communicative relations in history, in which poems, the living world and history are integrated. In this sense, the study of the third relation is both literary study and historical study. The historical study of the third relation does not mean historical background often mentioned in past literary studies, as historical background exists behind poems but does not consist in poems per se. The living world of the third relation does not exist behind the texts of poems but within the texts, which means that the literary study of the third relation converges with historical study, being both literary study and historical study. The study of the third relation also looks into the specific conditions giving rise to the texts of poems, and therefore sometimes the study of literary archaeology may be far away from the texts of poems but will finally return to poems per se, providing historical direct conditions for the study of poetic texts, or providing a basis of the living world.

Due to its different nature, the construction of the third relation is inevitably different from that of the influence relation or the parallel relation. The third relation has an inter-media between literatures of different states and nations, that is, the so-called archaeological level, which is the living world developed through communication and a critical factor for establishing the indirect literary relation. The following is a simple diagram drawn according to the above description. 


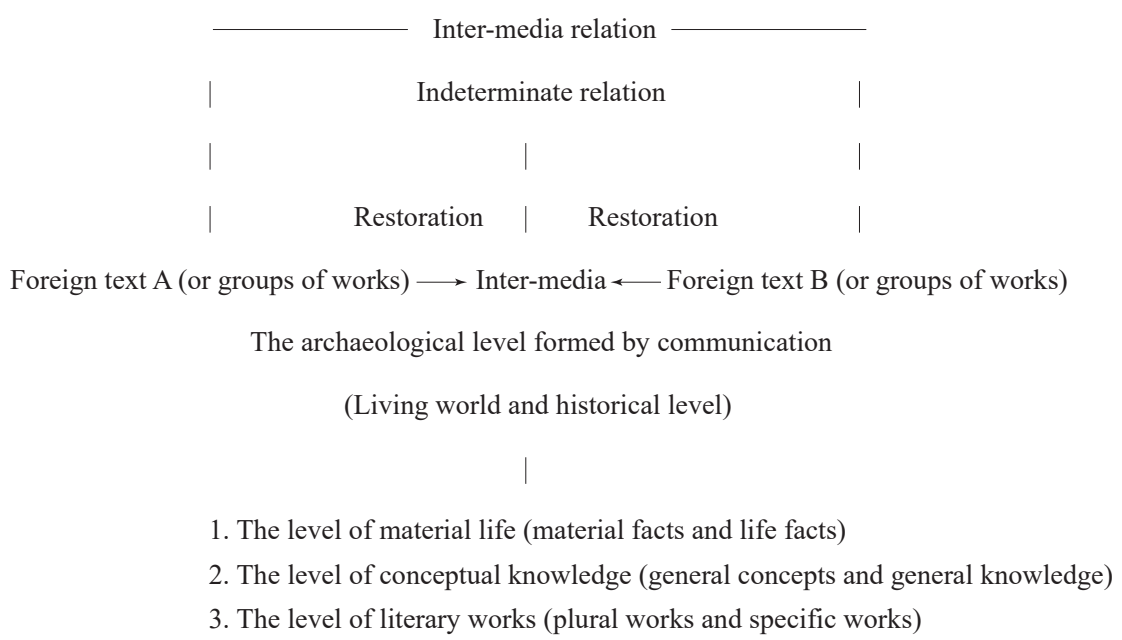

There are several terms for inter-media, as it consists of several levels. The archaeological level is between literary relations, and works are indirectly related via the archaeological level, which is therefore named intermedia. For today's scholars, inter-media is history that has already vanished, and the archaeological level that can be presented only through restoration. For poets, it is the living world and the daily life of the time when they live. The living world as the archaeological level occupies a central position in such relations, literary archaeology is restoration and research addressing the archaeological level, and the third study addresses literary relations developed around the archaeological level of inter-media.

The archaeological level consists of three sub-levels, the most fundamental of which consists of material facts and life facts, which may be called the material level and the living level. The second level consists of the concept level and the knowledge level. The third level is the literary level, consisting of similar plural works and specific works. These are three levels existing beyond selected $\mathrm{AB}$ texts, which are closely related to $\mathrm{AB}$ texts under study. Such a structure is artificially separated, as the archaeological level, in fact, consists of levels of different nature, which requires comprehensive study. Literary archaeology and the third study as two supporting points are closely related. It is literary archaeology to recover the living world, and it is still literary archaeology when the communication between the living worlds of two countries is studied, but such a study also addresses the third relation, as the study is about the communication between two living worlds and their literary relations.

The indirect influence relation and the third relation look somehow similar but are essentially different. The communication of the third relation is not conducted at the literary level but in the living world, which is still a funda- 
mental difference from the indirect influence relation and also a fundamental difference from mesology of Comparative Literature. The communication between literatures and the communication between living worlds belong to two completely different fields, and therefore have different nature and specific forms.

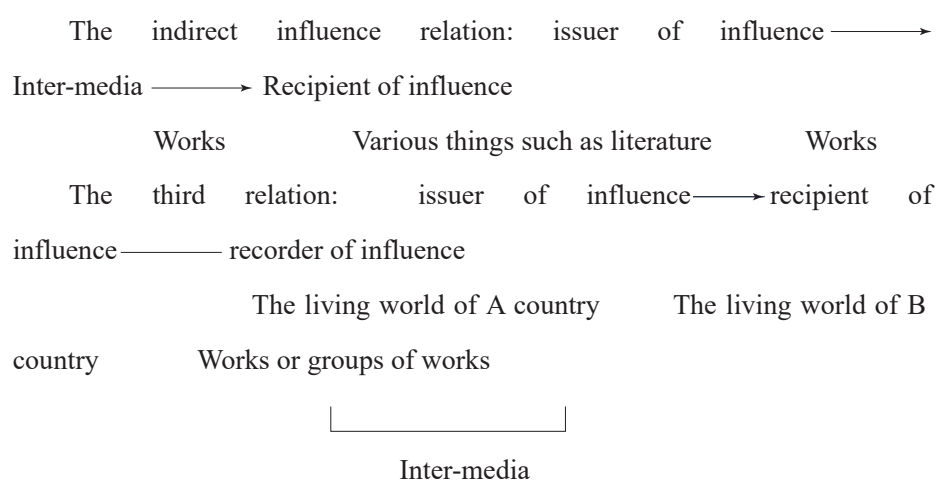

This simple relation diagram shows that the third relation indeed shares similar factors with the indirect influence relation, but the two have different specific forms: the recipient of influence in the influence relation is the poet or the literary work, but in the third relation the poet or the work is not the recipient of influence, the living world is the recipient of influence, while the poet is only a recorder of the communication between living worlds. In fact, in light of the similarity of similar factors, there are some differences among the influence relation, the parallel relation and the third relation: the similar factors of the influence relation have the highest similarity, while those of the parallel relation have the lowest similarity; the similarity of similar factors of the third relation is between the influence relation and the parallel relation, lower than that of the influence relation and higher than that of the parallel relation. The third relation, with characteristics of both the influence relation and the parallelism, seems both related and unrelated. The influence relation, which is the foundation for the inception of Comparative Literature, is the primary relation. Parallel study, a development of the study on literary relations, is the secondary relation, established among fields without communicative relations. The third relation, developed from communicative relations at the level of the living world, is between these two relations, and therefore can be called the third study. It should be noted that subversive relations of reverse communication may be found in both the influence relation and the third relation. In subversive communicative relations, the similarity of similar factors may become very low or even disappear altogether, leaving only opposite factors. However, this does not tantamount to the inexistence of the 
influence relation or the third relation, because so long as the relation of origin and development exists there is the influence relation or the third relation.

There is an order of time in the discovery of literary relations, which does not mean that there is an order of time regarding the facts of literary relations. The third relation does not necessarily follow the influence relation or the parallel relation, as it may be found where there is no influence relation or parallel relation at all. Sometimes the third relation coexists with the influence relation, which case not only calls for influence studies but also requires the study on the third relation. The study on the third relation cannot replace the study on influence or the parallel study, as they are on different literary relations and do not replace each other. The study on literary relations is not to simplify facts of literary relations to fewer types of relations, but to discover more literary relations, thus restoring facts concerning literary relations. Only studies are conducted according to facts of literary relations can the study on literary relations be truly promoted.

\section{Cases of the Third Relation: Willow Garlands and Willow Wreaths in Chinese and Japanese Poetry}

Manyoshu, the earliest waka collection in Japan, incudes nine wakas describing willow garlands, which refer to circlets made of willow twigs worn on heads.

梅の花咲きたる園の青柳は蘰にすべく成りにけらずや。1

梅花开园中, 青柳吐新芽。似已可折取, 柳蘰饰柔发。

While wintersweet blooms in the garden,

Green willows shoot out buds.

Their twigs appear ready for plucking,

To be made into garlands for soft hair.

SEUNI AHATANO DAIBU, N817

梅の花咲きたる園の青柳を縸にしつつ遊び暮さな。2

梅花园中开, 青柳可为蘰。戏柳又戏春, 举杯消春宴。

Wintersweet blooms in the garden,

Willows turn green ready for garlands.

Let's play with willows and spring,

Propose a toast to celebrate our spring feast.

SEUKEN TOSHINO MOMOMURA, N825

1 Ichinosuke Takagi et al ed., Manyoshu, Vol.2, A Collection of Classical Japanese Literature, Iwanami Shoten, 1962, P.75.

2 Ichinosuke Takagi et al ed., Manyoshu, Vol.2, A Collection of Classical Japanese Literature, Iwanami Shoten, 1962, P.77. 
春柳蘰に折りし梅の花誰か浮べし酒坏の上に。3

春来遍新柳, 折取为柳蘰。何人采梅花, 浮于酒杯上。

New willows sprout everywhere in spring,

Their twigs are plucked to make willow garlands.

Who's also collected a plum blossom,

Which floats in a wine cup.

IKINOSAKUWAN SONSHINOWO TIKATA, N840

「柳を詠む(咏柳)」

霜枯れの冬の柳は見る人の縸にすべく萌えにけるかも。4

寒霜草木枯, 浅冬柳芽见。嫩芽已满目, 似可为柳蘰。

While vegetation withers under cold frost,

Willow buds appear in early winter.

With tender buds seen everywhere,

Willow twigs seem ready for garlands.

N1846

ももしきの大宮人の縸ける垂柳は見れど飽かぬかも。 5

皇城宫中人, 头戴青柳蘰。柳蘰青欲滴, 看时永无厌。

People in the palaces of the capital,

Wear garlands made of green willow twigs.

Willow garlands are so tenderly green,

That they are never eyesore

N1852

「蘰を贈る (赠柳縸) 」A Willow Garland for Beloved

大夫が伏し居嘆きて造りたるしだり柳の蘰せ吾妹。6

铁石心肠人, 仰伏皆叹息。垂柳正青青, 绾柳思吾妹。

I, a person with a heart of steel,

Am sighing in every single move.

Weeping willows are green,

I make a garland thinking of my beloved.

N1924

3 Ichinosuke Takagi et al ed., Manyoshu, Vol.2, A Collection of Classical Japanese Literature, Iwanami Shoten, 1962, P.79.

4 Ichinosuke Takagi et al ed., Manyoshu, Vol.3, A Collection of Classical Japanese Literature, Iwanami Shoten, 1962, P.61.

5 Ichinosuke Takagi et al ed., Manyoshu, Vol.3, A Collection of Classical Japanese Literature, Iwanami Shoten, 1962, P.61.

6 Ichinosuke Takagi et al ed., Manyoshu, Vol.3, A Collection of Classical Japanese Literature, Iwanami Shoten, 1962, P.75. 
しなざかる越の君らとかくしこそ楊䕕き樂しく遊ばめ。7

越中诸君聚, 如此为柳蘰。头上戴柳縸, 杯酒且宴乐。

Gentlemen of Koshinaka gathered together,

And made willow garlands for the event.

Wearing garlands on head,

They drank and feasted.

右、郡司已下子弟已上诸人多集此会。因守大伴宿祢家持作此歌也。

Several people from the government offices had a gather-together. This song was made when they stayed at the home of Ootomo Sukune.

Ōtomo no Yakamochi, N4071

「二月十九日、左大臣橘の家の宴にして、攀ぢ折れる柳の条を見る歌一首 (二 月十九日、左大臣橘家宴攀折柳条而歌一首)」[The song was composed at a family feast held at the home of the Minister of Left on February 29]

青柳の上枝攀ぢ取り蘰くは君が屋戸にし千年壽くとそ。8

攀折柳枝梢, 绾绕为柳蘰。君祈家业兴, 无衰寿千年。

Willow twigs were plucked from willow branches,

Willow garlands were made by twisting these twigs.

We wish that your family prosper,

And last a thousand years without declining.

Ōtomo no Yakamochi, N4289

Where did the willow garlands in these wakas originate? Sakurai Mitsusuru deems that they were from the practice of Plucking Willow Twigs in China. That is to say, she thinks that there is a relation of influence between songs on willow garlands and Plucking Willow Twigs in China.

Willow Wreaths and Willow Garlands

In China, from the ancient time, there has been a practice of making willow twigs into a wreath as a gift for a friend departing for a journey in the hope that he would come back safe and sound. "Plucking willow twigs" was one of the topics in "yuefu" ballads of the Han dynasty, which was a kind of song on farewell played by flutes. Wang Zhihuan, a Tang poet wrote a poem entitled "Farewell":

Willow trees swayed by spring breeze,/Stand by the imperial river making a green scene./Willow twigs are not easy to pluck recently,/ Because there are too many people bidding farewell.

7 Ichinosuke Takagi et al ed., Manyoshu, Vol.4, A Collection of Classical Japanese Literature, Iwanami Shoten, 1963, P.269.

8 Ichinosuke Takagi et al ed., Manyoshu, Vol.4, A Collection of Classical Japanese Literature, Iwanami Shoten, 1963, P.387. 
In China, the character for "willow" (“柳”) is homophonic with that for "stay" (“留”). People pluck willow twigs perhaps they want their departing friends to stay. The character for "wreath" (“环”) is homophonic with that for "return"(“还”), and so it seems that the making of wreaths can be interpreted as wishing friends to return soon. ${ }^{9}$

Sakurai Mitsuru's explanation is quite popular in the academic community of Japan. Similar explanations can be found in a dictionary on botany. ${ }^{10}$ However, before the mid-Tang, no willow wreath or anything like a willow wreath appeared in any song entitled "Plucking Willow Twigs", and the term “柳环” (willow wreath) is not found in any ancient literature. Since nothing like willow garlands appears in songs about plucking willow twigs, what was given in a farewell bid with willow twigs plucked?

A Song on Plucking Willow Twigs

上马不捉鞭, 反折杨柳枝。

蹀坐吹长笛, 愁杀行客儿。

腹中愁不乐, 愿作郎马鞭。

出入擐郎臂, 蹀坐郎膝边。

Instead of taking a horsewhip,

He plucked willow twigs before mounting a horse.

He played a long flute while squatting,

His sorrows touched travelers.

Full of melancholy in mind, I wish to be your horsewhip.

Then I would be close to your arms

And sit by your knees. ${ }^{11}$

9 Sakurai Mitsuru, Folklore of Flowers, A Collection of Sakurai Mitsuru's Works, Vol.9, Kodansha, 2000, PP.67-68. The same idea can be found in more Japanese academic works, such as Tomo Yanagida's The Culture of Willows. This version can also be found in An Annotated Collection of Ballads in the Middle Ages (the AzuchiMomoyama period). "Willow twigs were plucked and made into wreaths....Willow twigs were made into wreaths because the Chinese character for "wreath" ("环") is homophonic with that for "return" (“还”), meaning returning soon." The Culture of Willows, Tankosha, 1995, P.187

10 "In the Tomb-Sweeping Festival, willow twigs were used to ignite new fire, and willow twigs were also placed on doors and eaves, or on hair. Similar customs can also be found in "Plucking Willow Twigs". When a close friend or relative is about to depart for a journey, people plucked willow twigs by water and made them into wreaths as gifts. It is said that the Chinese character for "wreath" (“环”) is homophonic with that for "return" (“还”), so people wished that the traveler would be blessed by the spiritual power of willow, and also that the traveler would not lose his soul for the fatigue of travel." (The Society on Plant Culture ed., An Illustrated Encyclopedia on Flowers and Trees, Tokyo: Kashiwashobo, 1996, P.458.)

11 [Song] Guo Maoqian ed., Hengchui Ballads in A Collection of Yuefu Songs, Vol.25 
Before mounting a horse, the man did not take a horsewhip but plucked willow twigs instead. Thus it can be concluded that he did not hold a willow wreath, but a willow twig, as only a willow twig could be used as a horsewhip. A poem by Cui Guofu of the Tang dynasty can also prove that willow twigs instead of willow wreaths were given in a farewell.

Ballad on a Happy Young Man

Cui Guofu

遗却珊瑚鞭, 白马娇不行。

章台折杨柳, 春日路旁情。

While the coral whip was lost,

The white horse stood still coquettishly.

He plucked willow twigs from wayside,

To bid farewell to beauties in springtide. ${ }^{12}$

A young man, when bidding farewell with prostitutes, found that he lost his horsewhip and thus plucked willow twigs as a horsewhip. An ancient Japanese painter illustrated Tang poems. The following is an illustration on Cui Guofu's poem.

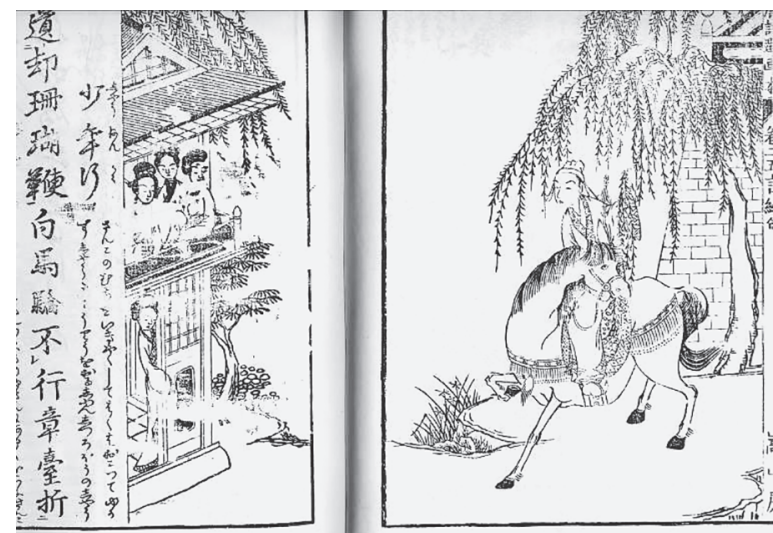

Illustration by Katsushika Hokusai on "Ballad on a Happy Young Men"13

This is an illustration by Katsushika Hokusai in Selections of Illustrated Tang Poems (1793). The young man held willow twigs in hand instead of a willow circlet. There is a perplexing problem with Katsushika Hokusai's

(Book II), Zhonghua Book Company, 1979, P.370.

12 Zaqu Lyrics, in The Complete Collection of Tang Poems, Vol.24 (Book II), Zhonghua Book Company, P.327.

13 Edited and annotated by Kobayashi Shinbei and Takai Ranzan, and drawn by Kitao Shigemasa and Katsushika Hokusai et al, Selections of Illustrated Tang Poems, 1996, PP.680-681 (This is a copy of its first version in 1793). 
illustration: according to the custom of "Plucking Willow Twigs", one willow twig should be given; but instead of one, the young man held more than one in hand. Many poems are about giving one twig, which prove that it is customary practice to give one willow twig.

Plucking Willow Twigs

Zhang $\mathrm{Hu}$

凝碧池边敛翠眉, 景阳楼下绾青丝。

那胜妃子朝元阁, 玉手和烟弄一枝。

Waving willow branches on the Blue Jade Pond imitate frowning brows,

Or turn into fine and soft black hair under the Sunny Scene Pavilion.

How can they emulate an imperial concubine by the Sage Worshipping Tower,

Who is fondling a misty willow twig in her jade hands? ${ }^{14}$

This poem is about a lady plucking a willow twig as a gift for her beloved. Zhang Jiuling's "Plucking Willow Twigs", "One willow twig is not a precious gift, it only stands for spring in my hometown." 15 Yang Juyuan's "In Reply to Scholar Lian's Plucking Willow Twig Song", "Willow trees by the riverside are like green misty silk,/I curbed my horse, requesting my friend of a willow twig." 16 "Plucking Willow Twigs" of Wen Yanbo in the Song dynasty, "When I see a wild goose from outside the Great Wall,/I would send you another willow twig of the spring." 17 Wang Shen's "Lyric on Willow Twigs", "The willow tree sprouts its misty silky branches/Drooping heavy like snowy brooms./The most romantic thing in the world is no other than the willow tree, as a willow twig is always eagerly given in farewell." 18 Since one willow twig was presented as a gift in farewell, why does the young man in Katsushika Hokusai's illustration hold more than one twig? Was it because Katsushika Hokusai didn't know the custom of plucking a willow twig in

14 Poems of Zhang Hu in The Complete Collection of Tang Poems, Vol.511 (Book VIII), Zhonghua Book Company, 1999, P.5880.

15 [Song] Li Fang et al ed., Finest Blossoms in the Garden of Literature, Vol.280 (Book II), Zhonghua Book Company, 1966, P.1030.

16 [Ming] Cao Xuequan ed., Shicang's Anthology of Poetry. Mid-Tang 18, Vol.64, The Complete Library of the Four Treasuries at Wenjin Chamber, Vol.464, The Commercial Press, 2005, P.102.

17 [Song] Chen Si ed., A Collection of Works by Celebrities in the Song Dynasty, Vol.7, The Complete Library of the Four Treasuries at Wenjin Chamber, Vol.455, The Commercial Press, 2005, P.466.

18 [Song] Wang Xin, A Collection of Wang Shen's Works, Vol.3, The Complete Library of the Four Treasuries at Wenjin Chamber, Vol.393, The Commercial Press, 2005, P.645. 
farewell? However, with a careful examination of the young man in the illustration, we can see that he holds four willow twigs in hand, and there are four prostitutes, one twig for one person. The living world of plucking willow twigs in farewell is restored in the above, according to which we can see that the songs on willow garlands in Manyoshu have no relation of influence with the Chinese practice of plucking willow twigs. Such a study on the relation of influence is not correct.

Things like willow garlands also appeared in this literary history of China, that is, willow circlets described in poems and essays, but they were not named willow wreaths.

Ode on Willow Circlets

[Yuan] Wang Yun

While warm mist floats, by the green willow bridge, willow twigs are plucked to make soft circlets.

All the spring angst and heat are cast into the depth of the blue waves. By a wild brook, a group of beauties in golden silk dresses sing songs and wear green jade circlets.

All ill luck flows away with water, with only spring scenes revisit our wine goblets.

Let me ask how long will spring stay? One fifth of spring has passed, and peach blossoms float farther and farther away with water in morning breeze.

Where are they going to send the spring sorrows? Go to the east of Hunan with a ring of clear shadow.

Walking along the spring brook, I'm happy to have a companion. Let's drink a cup by the riverside.

...19

This poem is about the mood of wearing willow circlets on the $3^{\text {rd }}$ day of the $3^{\text {rd }}$ lunar month (known as Double Third Festival), and mentions willow circlets several times. The significance of willow circlets lies in its supposed function of removing illness, which is not unrelated with life worship. Several other poems of Wang Yun mention willow circlets. For example, in "Three Poems in Reply", "Willow circlets shimmer in the wind and ride on ripples,/Blisses come from afar to offer peace of time." ${ }^{20}$ Also, in "A Poem

19 [Yuan] Wang Yun, A Collection of Wang Yun's Poems, Vol.77, The Complete Library of the Four Treasuries at Wenjin Chamber, Vol.401, The Commercial Press, 2005, P.321.

20 [Yuan] Wang Yun, A Collection of Wang Yun's Poems, Vol.18, The Complete Library of the Four Treasuries at Wenjin Chamber, Vol.401, The Commercial Press, 2005, P.75. 
Composed on the Double Third Festival in the Lin's Garden", "Everyone wore a willow circlet to ward off evil spirits,/Offsetting white hair unlike blooming branches." 21 Wang Yun elaborated on the customs of the Double Third Festival in "A Party for Warding off Evil Spirits", "It happened to be a year of serpent, another year of prosperity. Therefore, I invited two or three good friends to have a party at the Lin's garden. All things were properly and sincerely handled. As an old routine, each person prepared a pot of wine, a bunch of flowers, several coins and one willow twig circlet, and colorful clothes were preferred. All other supplies were prepared by the garden owner. With orchids in hand, we attempted to restore the story taking place at the Orchid Pavilion by drinking wine and composing poems."22 Wang Yun had several gatherings with his friends at the Lin's Garden, and each time, they plucked willow twigs to make circlets.

Obviously, there are some similar factors between the songs on willow garlands in Manyoshu and Wang Yun's poems on willow circlets: First, the songs on willow garlands in Manyoshu are mostly about banquets, with 817, $825,840,4071$ and 4289 being all about banquets. If No. 4238 is included, there are 6 in total, accounting for two-thirds of the total number of wakas about willow garlands. Wang Yun's poems on willow circlets are also all related to banquets. Obviously the two are similar in this regard. Second, No.1846 and 1852 wakas are about the joy of spring, which is also a main topic found in Wang Yun's poems. No. 1924 is about the joy of spring and also the love between men and women. Wang Yun's poems do not describe such love, but the expression of love between men and women was actually an activity in the Double Third Festival, and it is normal to find such expressions in songs of willow garlands. Third, of the nine wakas on willow garlands, none is about farewell, which is a very prominent characteristic. If these wakas were influenced by China's "Plucking Willow Twigs", contents on farewell should be found. But no such content is found, and this means that these wakas are not related to China's "Plucking Willow Twigs".

The above similarities seem to suffice to prove the relation of influence between the songs on willow garlands in Japan and the poems on willow circlets in China. However, the similarity between these two kinds of poems is far from that constituting the relation of influence, as there is no similar trace between any wordings of the songs on willow garlands and the poems

21 [Yuan] Wang Yun, A Collection of Wang Yun's Poems, Vol.18, The Complete Library of the Four Treasuries at Wenjin Chamber, Vol.401, The Commercial Press, 2005, P.75.

22 [Yuan] Wang Yun, A Collection of Wang Yun's Poems, Vol.70, The Complete Library of the Four Treasuries at Wenjin Chamber, Vol.401, The Commercial Press, 2005, P.294. 
on willow circlets, and it is difficult to ascertain the influence relation at the textual level. If it is deemed that no influence relation exists between the two, how should the above similarities be explained? The study on literary relations is therefore in a predicament. However, there is a completely objective factor, which can fully prove the inexistence of any influence relation. That is, as Wang Yun was a poet of the Yuan dynasty, it was impossible for Manyoshu to be influenced by his poems. After the mid-Tang, willow circlets used at the Double Third Festival were used for farewell. Liu Yuxi (772-842) wrote in his "Poems on Willow Twigs (7)", "By the imperial path, willow branches droop to the ground by blue gates, like a thousand gold threads and ten thousand silk laces. Now I make a true love knot with willow twigs, knowing not whether the traveler understands my attachment."23 Zhang Qiao's "To My Friend of Weiyang", "I coiled up willow twigs by the river of farewell,/As my friend will take a journey across numerous mountains and rivers." 24 The word "coil" means that willow twigs were made into circlets. Bai Juyi's "Eight Lyrics on Willow Twigs (6)", "Twigs were peeled and coiled into silver shapes,/Leaves were rolled to make music of flutes." $25 \mathrm{Su}$ Xiaoxiao plucked willow twigs, peeled off their green skin, coiled them into a ringshaped circlet, and wore it on her head. Therefore, Bai Juyi said "silver ring shapes". Willow circlets started to be used in the practice of plucking willow twigs after the mid-Tang, but it was impossible to have any influence relation with the songs on willow garlands in Manyoshu, because songs on plucking willow twigs in the mid-Tang were also later than Manyoshu, unable to exert any influence on Manyoshu.

Since the songs on willow garlands in Manyosh $u$ are unlikely to have any influence relation with poems on willow circlets in China, are they of a parallel relation? The similarity of the two is not very high, and it seems that they have a parallel relation. However, the songs on willow garlands and the poems on willow circlets are both on willow coils which are completely the same, both of them were used in banquets and expressed the joy of spring. Their similarity is therefore higher than that of the parallel relation, and the two do not seem to have a parallel relation. In fact, the third relation may exist between the two. That is to say, Japanese singers brought willow circlets used at the Double Third Festival of China to Japan, and Japanese singers described willow circlets. Hence the appearance of songs on willow garlands

23 Poems of Liu Yuxi in The Complete Collection of Tang Poems, Vol.365 (Book XI), Zhonghua Book Company, October 1992, P.4113.

24 Poems of Zhang Qiao in The Complete Collection of Tang Poems, Vol.639 (Book XIX), Zhonghua Book Company, October 1992, P.7329.

25 Xie Siwei, An Annotated Collection of Bai Juyi's Poems, Vol.31 (Book V), Zhonghua Book Company, 2006, P.2418. 
in Manyoshu. Chinese poets described willow circlets in the living world of China. As a result, similar things appeared in Chinese and Japanese poems. A similar living world was produced through communication, and the third relation occurred. Then did any communication occur in the living world? One of the conditions of communication was that willow circlets appeared in China earlier than Manyoshu of Japan. The earliest record on wearing willow circlets at the Double Third Festival in the history of China was made in the fourth year of Jinglong period in the reign of Emperor Zhongzong of Tang (710). Duan Chengshi of Tang recorded in Youyang Essays, "On the $3^{\text {rd }}$ day of the $3^{\text {rd }}$ lunar month, courtiers were given circlets made of fine willow twigs, which were said to be able to ward off scorpions and other poisonous insects." 26 This is a creditable documentary record of the Tang dynasty. The record in Book of Tang is more comprehensive:

In spring of the fourth year...in the $3^{\text {rd }}$ month, the emperor arrived at the Wei Pavilion, held a banquet, and gave ministers willow circlets to ward off evil spirits. ${ }^{27}$

On the Double Third Festival of the fourth year of Jinglong period, a banquet on a winding stream was held, during which Emperor Zhongzong of Tang gave his ministers willow circlets. From then on, it became a customary practice for the emperor to give willow circlets on the Double Third Festival every year. New Book of Tang records, "Only the prime minister and the grand secretary could accompany the emperor in his banquets and outings. In spring, the emperor arrived at the Liyuan Garden and the Weishui River, and gave fine willow twig circlets to ward off evil spirits; in summer, the emperor held a banquet at a vinery and gave red cherries; in autumn, the emperor ascended the Ci'en Temple, while a monk presented chrysanthemum wine praying for longevity." 28 In spring, the emperor visited the Weishui River together with his prime minister and the grand secretary, held a banquet along the winding river and gave his ministers willow circlets for the purpose of warding off evil spirits.

Then when were willow circlets of Tang introduced to Japan? The earliest description of willow garlands in Manyosh $u$ was found in "32 Poems on the Plum Blossom Banquet" made in the second year of Tianping period (730). The earliest record on wearing willow circlet in China was found in the

26 [Tang] Duan Chengshi, Royalty of Youyang Essays, The Complete Library of the Four Treasuries at Wenjin Chamber, Vol.1047, P.639.

27 "Emperor Zhongzong" in "Biographic Sketches of Emperors No. 7", Book of Tang, Zhonghua Book Company, 1997, P.57.

28 "Wen Yizhong", "Collected Biographies No.127”, New Book of Tang, Vol.202, Zhonghua Book Company, 1997, P.1468. 
fourth year of Jinglong period in the reign of Emperor Zhongzong of Tang (710). From 710 to 730 , the eighth Japanese mission to Tang came to Chang'an from the first to the second years of Yanglao period (717-718). The main members of the mission included Tajihi no Agatamori, Abe no Yasumaro, Kibi no Makibi, Genbo, Ōtomo no Yamamori, Fujiwara no Umakai and Shinsei etc. Among the eighth mission, the most noteworthy person was Yamanoue no Okura, who also participated in the Plum Blossom Banquet. It was said that the preface to the "32 Poems on the Plum Blossom Banquet" was written by Yamanoue no Okura. Even though this was uncertain, it was doubtless that Yamanoue no Okura attended the Plum Blossom Banquet, as the No. 818 waka at the Banquet was written by him. Yamanoue no Okura visited Chang'an of the Tang dynasty and also appeared at the Plum Blossom Banquet, which showed that the information of wearing willow circlets at a banquet should be transferred by him. Yamanoue no Okura, who was accomplished in Chinese culture, should be interested in learning how the Tang court spent the Double Third Festival. He learned the practice of ministers wearing willow circlets and drinking in Chang'an and brought this information to Japan. In this way, willow garlands started to appear in Manyoshu. Based on this inference, it can be ascertained that due to the communication between the living worlds of China and Japan, willow garlands and songs on willow garlands appeared at banquets, and via willow garlands and willow circlets, the third relation occurred between Chinese and Japanese poems.

The similar factors in the third relation originate from the communication between living worlds, and therefore it is impossible to find any evidence of communication at the literary level to prove the influence relation, which is a difficulty encountered in the study of the third relation by the influence relation, and also a challenge for today's academic community. The third relation is open, because the communicative factors between living worlds are open, living worlds are also open, and any poet can freely describe a living world and its communicative factors. Therefore, the relation among poets is open and loose, unlike the influence relation, which is close. Only when we stick to empirical study can we restore the living world, and then move towards literary archaeology and the third relation.

\section{The Significance of the Third Relation}

The making of concepts is now popular in the academic community, as if new results can be obtained by making concepts. However, most newly made concepts are old concepts restructured, not differing much from old concepts in actual contents. Such making of concepts with only superficial change does not have any great significance. In fact, the making of concepts 
must be premised on the discovery of new facts; without discovery of any new concept, it is not necessary to make a concept. New facts, which were never discovered and studied, do not have names, and call for the making of concepts for naming for the convenience of study. The third relation is a concept created on the basis of discovering the third comparative literary relation, and therefore marks new targets of study and symbolizes the expansion of new fields of study for literary relations. The discovery and research on the third relation have major new significance:

First, the third relation is ubiquitous instead of being exceptional cases, and is therefore of general significance to the study of literary relations. The communicative relations in the living world are more diversified and extensive than those at the literary level, exerting a comprehensive influence on literary relations. If the third relation was not discovered, the study on literary relations would surely be affected. The third relation failed to be truly recognized by researchers because it was concealed. Since the modern times, literature and history have been completely separated, with literary researchers studying literature only and historians studying history only. Only when we return to the original facts of literary relations can we discover the third relation beyond the influence relation and the parallel relation. Scholars should be ready to discard all concepts and theories to return to the original state for primitive investigation so as to discover facts and truths covered by concepts and theories.

Second, the living world is included into the scope of research of literary relations, which not only expands the scope of research of literary relations but also restore the study of literary relations to the essential level of literature. The restriction of research to the influence relation of texts by giving up the essential relation between literature and the living world goes against the nature of poetry. For this reason, Rene Wellek criticized the study on influence relations as the study on literature trade. The study on the third relation can avoid the crisis of Comparative Literature pointed out by Wellek and bring the study on literary relations back to the genuine state of poetry, which is the fundamental direction for the study on literary relations.

Third, the construction of the third study calls for a re-examination of the history of the influence study and parallel study. Given only influence relations, many case studies could only be determined as influence relations or parallel relations. Upon a new study after the discovery of the third relation, what were determined as influence relations or parallel relations are not necessarily influence or parallel relations. This is true with the influence relation between the songs on willow garlands of Japan and the Chinese practice of plucking willow twigs. With a new study at the level of the living world, it is discovered that no influence relation at the literary level existed 
between the songs on willow garlands of Japan and the Chinese practice of plucking willow twigs, and that there was only the third relation between the songs on willow garlands and the poems on willow circlets. The third relation offers a more reliable and scientific approach of research, able to take the study on literary relations to a broader field of comprehensive study. 